\title{
Smartphone-Based Learning Media on Microscope Topic for High School Students
}

\author{
Nuraini Nadhiroh ${ }^{1, *}$ Insih Wilujeng ${ }^{2,}$ Aniesatus Sa'diyah ${ }^{1,}$ Sony Y. Erlangga ${ }^{1}$ \\ ${ }^{1}$ Master of Physics Education, Faculty of Mathematics and Natural Sciences, Universitas Negeri Yogyakarta, \\ Indonesia \\ ${ }^{2}$ Department of Science Education Program, Faculty of Mathematics and Natural Sciences, Universitas Negeri \\ Yogyakarta, Indoenesia \\ "Corresponding author. Email: nuraini0355pasca.2019@student.uny.ac.id
}

\begin{abstract}
One of the learning media with mobile technology that can be used for education is 'smartphone.' This study developed a smartphone-based learning media capable of supporting physics learning on Microscope topics for XI grade high school students with a specialization in Mathematics and Natural Sciences (MIPA). This development product is in the form of teaching materials that can be accessed through an application on a smartphone. This learning media is validated by media experts and content experts. The development model used is modified Borg \& Gall with seven stages, namely the preliminary research stage and information gathering, the planning stage, the preliminary product development stage, the design validation, the main product revision, the main field testing, and the operational product revision stage. The data obtained were analysed using equations and interpreted in the interpretation of the validation results assessment score. This development results reveal the validity value of smartphone-based learning media by content experts and media experts. The validity of media expert's states that it is valid for product development and the validity of material expert's states that the content developed in learning media is very valid. The accumulated student response to the application of smartphonebased learning media is very good.
\end{abstract}

Keywords: Learning media, Microscope, Smartphone

\section{INTRODUCTION}

The development of technology in the 21 st century is followed by developments in all aspects of life, including education. Education and technology are now closely related and influence each other [1]. Education with technology provides interesting learning innovations and provides easy access to knowledge [2]. Applied technology for education makes the use of technology more meaningful and useful. Technology is a positive tool to support the achievement of educational goals [3]. Technology also affects the development of educational curricula in three ways, i. e: (1) the use of new technology becomes the social goal of the curriculum, (2) technology provides resources for curriculum development, and (3) technology is able to provide tools to virtually assess various areas of practice [4].
The convenience offered by technology supports communication and interaction while studying. Accessing the material will be easier so that it can help facilitate the learning process [5]. One form of technology that is being widely used is the 'smartphone'. A survey conducted by the United States of 2,100 public school students in North Carolina in 2015 showed that $48 \%$ of 11 -year-olds own a smartphone and $85 \%$ of 14-year-olds own a smartphone [6]. Underage internet users in China reached 169 million, with details: $89.5 \%$ of elementary school students, $99.4 \%$ of junior high school students, and $96.3 \%$ of high school students. Overall, there are $92 \%$ of students who use smartphones to access the internet [7]. Based on data from the Ministry of Communication and Information Technology of the Republic of Indonesia, through its research with UNICEF on the behavior of children and adolescents using the internet. It is reported that there are around 
30 million children and adolescents in Indonesia who use the internet and digital media as the main communication channels [8].

Smartphones are now a lifestyle for Indonesian teenagers based on the high number of smartphone users. Even though smartphones have many positive aspects such as making communication easier, making it easier to reach the internet and other convenience features [9]. However, this positive aspect of smartphones has not been fully utilized. Even when smartphones are used in the long term (used continuously until it consumes time), it can have a negative impact on students [10][11]. For example, causing physical health problems, psychological problems, social or affecting the learning environment [12]. The use of smartphones in the digital era can be done effectively. So that social media can be used positively as a forum for virtual expression.

Education at the high school level needs to integrate learning with smartphone technology. Especially, how teachers manage technology to control the use of smartphones by students. Teachers must be able to lead students to use smartphones wisely [13]. The development of smartphone-based learning media by teachers is an effective smartphone utilization solution [14]. This has a positive impact on students. In addition to adding value to the functions and benefits of smartphones for learning, the academic performance of students will increase [15]. This can also have a positive impact on aspects of knowledge, aspects of skills, and attitudes [16]. The use of smartphones for learning activities affects the academic achievement of students [17]. Smartphonebased learning media can also be used anytime and anywhere, and train the independence of students in exploring knowledge [14][18].

Microscope sub topic for XI grade high school students focuses on parts of the microscope and the formation of object images on the microscope. Smartphone-based learning media provides a clearer picture of the parts of the microscope and clearer explanation about how light forms shadows on objects on the microscope [19]. Microscope is a part of Optics lesson in physics learning that explains observable phenomena based on human experience and experiments in detail [20]. The learning media developed not only displays theory, but provides a detailed description of the microscope, from theory to problem solving [21].

Smart App Creator (SAC) is a software that can be used in the development of learning media. The software displays static theory and simulation. Even though the development of teaching materials will be far more optimal when it can be used in detail. However, SAC can be used to create multimedia content for mobile devices/smartphones for educational use. SAC is compatible with iOS and android operating systems. The output extensions of this software are apk, xcodeproj, HTML5, and exe. this allows the resulting application to be compatible with a wide range of touch devices and monitors [22]. So, in making smartphone-based learning media, SAC software can be used with the results of the application in the apk format that is easy to download and use by students. The development of learning media also needs to be developed in this digital era. The media developed in this study contained optical material about microscopes for high schools. This media is developed and tested for its feasibility and practicality before being used for a larger scope.

\section{RESEARCH METHOD}

This development design used Research and Development (R\&D) design. This research used the Borg \& Gall model which has ten development stages, i.e.: (1) Research and information collecting; (2) Planning; (3) Develop a preliminary form of product; (4) Preliminary field testing; (5) Main product revision; (6) Main field testing; (7) Operational product revision; (8) Operational field testing; (9) Final product revision; (10) Dissemination and implementation [23]. Researchers modify the stages of development according to the objectives of this research. The developments used include (1) Preliminary research and information collecting; (2) Planning; (3) Develop a preliminary form of product; (4) Design Validation; (5) Main product revision; (6) Main field testing; and (7) Operational product revision [24]. This research was conducted at SMA N 1 Ngaglik, Yogyakarta. The subjects in this study were students of class XI MIPA 2 (class XI with a specialization in Mathematics and Natural Sciences) SMA N 1 Ngaglik.

The stages of the preliminary research and information collecting were carried out by conducting a field survey to identify problems that occurred in learning physics and analysis on students at SMA N 1 Ngaglik, especially in class XI MIPA. The survey was conducted by using the observation method.

The second stage is the planning stage by designing a storyboard. This stage prepared the concepts of smartphone-based learning media development, curriculum in the form of basic competencies, and 
learning indicators from the topic of microscope. The third stage is the development of preliminary products. This stage consisted of determining the source of content, formulating basic competencies, designing the appearance and content of learning media, and packaging attractive learning media.

The fourth stage is designed validation by assessing the product. The validation stage was carried out to obtain the feasibility value of the experts. Validation was carried out by content and media experts, each validation team consisting of two experts. The result of this validation is a product in the form of smartphone-based learning media that is suitable for use and is feasible to be tested on students. The fifth stage is design revision. At this stage, the product design that has been validated was revised based on comments and suggestions from content experts and media experts.

The sixth stage is product testing. Product trials were carried out at SMA N 1 Ngaglik in class XI MIPA with the aim of seeing students' responses to this media. The results of the product trials show that this Smartphone-based learning media product has met the eligibility requirements or is suitable for use by students. The last stage, product revision, aims to revise the product according to the input and suggestions from the sixth stage. The weaknesses found are fixed and refined so that the product can meet the requirements for use and is suitable for use by students. This development stage is presented in Figure 1.

The data analysis techniques were product validation analysis and practicality analysis. Lecturers carry out product validation, and students carry out practicality. The score of each statement for all validation results by the validator and the students' responses were analyzed and expressed in the form of an equation [25]:

$\mathrm{SS}=\frac{\overline{\mathrm{SS}}}{\mathrm{S}_{\mathrm{m}}}$

$\mathrm{SS}$ is the validity value of media experts and content experts, and the practicality value obtained from the responses of students. $\overline{\mathrm{SS}}$ is the sum of the average score of each indicator of the validity of media experts, content experts, and student responses, and $\mathrm{S}_{\mathrm{m}}$ is the sum of sub indicator. Table 1 presents the assessment criteria used in this study to interpret the results of expert validation and the results of practicality tests on students [26].

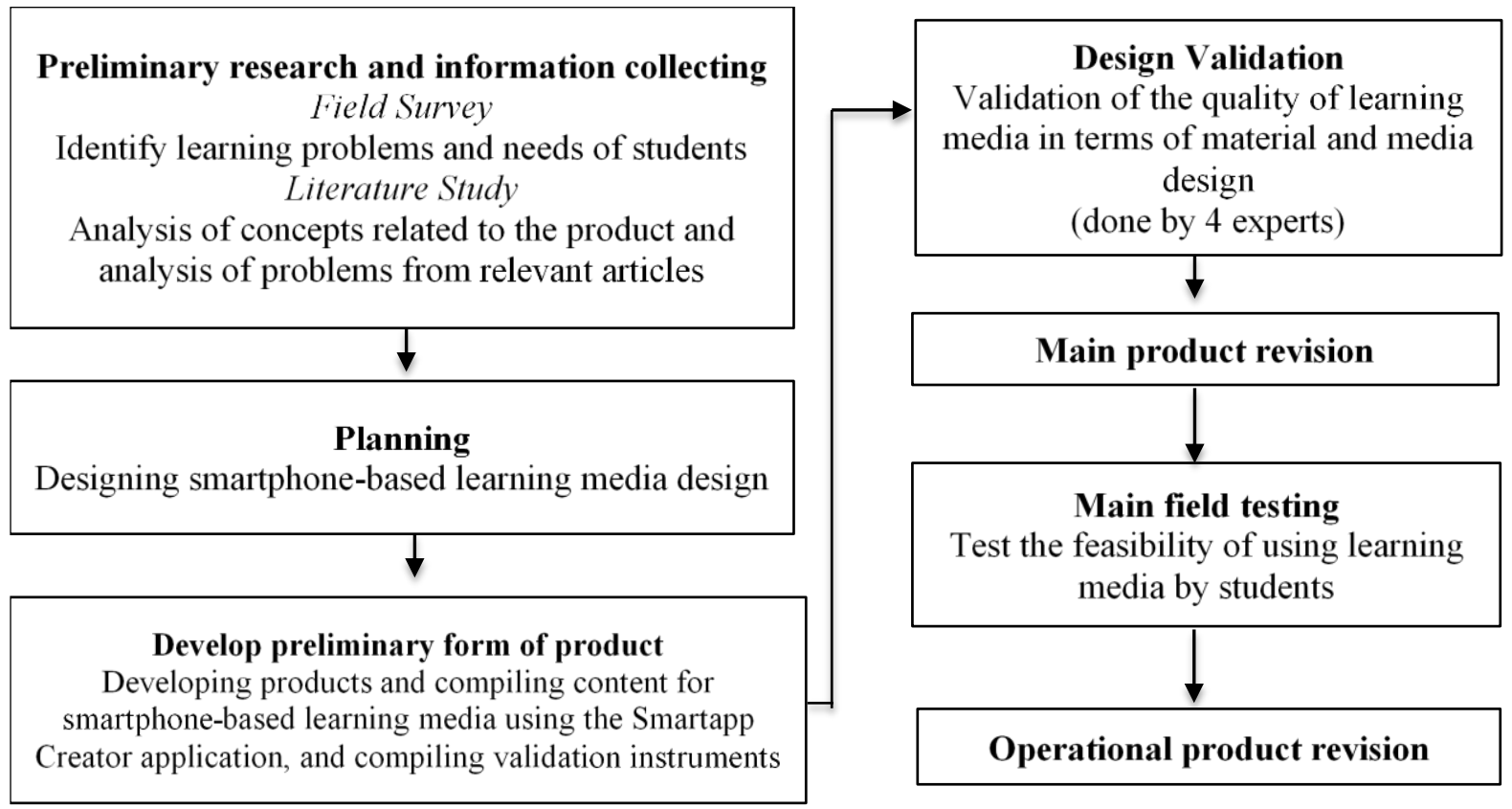

Figure 1. Research and development stage of smartphone based learning media 
Table 1. Interpretation of the validation result assessment score

\begin{tabular}{|c|c|l|}
\hline Interval & $\begin{array}{c}\text { Assessment } \\
\text { Criteria }\end{array}$ & \multicolumn{1}{|c|}{ Conclusion } \\
\hline $3,26-4,00$ & Strongly Valid & $\begin{array}{l}\text { Can be used } \\
\text { without revision }\end{array}$ \\
\hline $2,51-3,25$ & Valid & $\begin{array}{l}\text { Can be used } \\
\text { with minor } \\
\text { revisions }\end{array}$ \\
\hline $1,76-2,50$ & Invalid & $\begin{array}{l}\text { Cannot be used } \\
\text { because it } \\
\text { needs revision }\end{array}$ \\
\hline $1,00-1,75$ & $\begin{array}{c}\text { Strongly } \\
\text { Invalid }\end{array}$ & $\begin{array}{c}\text { Cannot be used } \\
\text { at all }\end{array}$ \\
\hline
\end{tabular}

If the validation and assessment results show a value of less than 2.51, the product will be revised or corrected according to suggestions and comments. However, if the results show more than 2.51 then the product is suitable for use in learning.

\section{RESULTS AND DISCUSSION}

This development research consists of three main stages, the preliminary research stage, the product design and development stage, and the validation and evaluation stage. The results of each stage are explained at the following points.

\subsection{Preliminary Research Stage}

Field survey. After conducting a field survey using the classroom observation method, it was found that the learning outcomes of class XI MIPA students in learning physics were quite good. However, the enthusiasm of students in learning physics is lacking [27]. It was also found that the use of smartphones for learning by students was not optimal, while the school allowed students to bring smartphones [28].

Literature review. After examining various relevant sources, the results show that the use of smartphones in education is still low. Smartphones as a technology that is easily accessible to students are still used only for social media but have not been used to support learning [10]. Internet connection that is connected directly to a smartphone is very easily accessible to students. It also has not been used to support learning and improve students' abilities [29].

\subsection{Product Design and Development Stage}

The product developed was a smartphone-based learning media suitable for use in learning with a microscope topic. The media developed was adjusted to the indicator of learning objectives from the microscope topic. SAC software can be downloaded via UC Browser or google. The design process began with inserting the microscope topic into the SAC software and compiling it according to the storyboard referring to the learning achievement indicators. The main material was supported by pictures and videos. Editing used the features provided by SAC, such as font selection, image selection, background, image editing, video, simulation input with less complicated editing [22]. The last stage is to change the media that has been designed and developed at SAC into an application in the form of an apk file. This apk file was downloaded by students and installed on their smartphone. Figure 2,3,4, and 5 shows some parts of the smartphone-based physics learning media on the microscope topic.

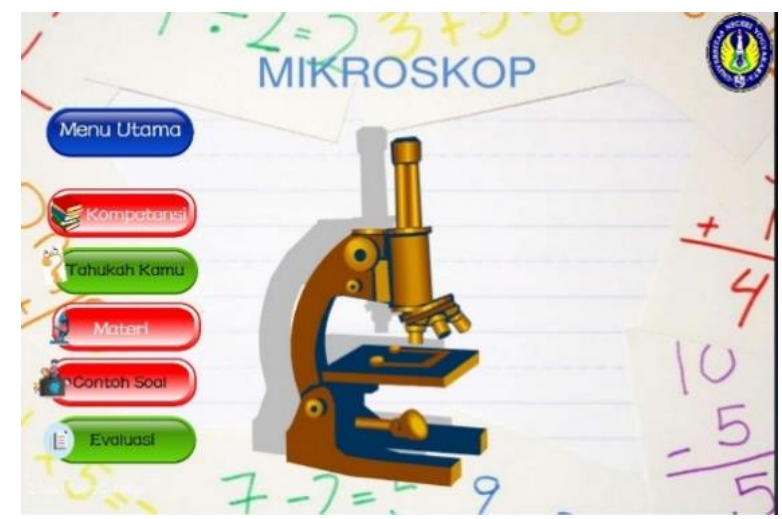

Figure 2 Home screen

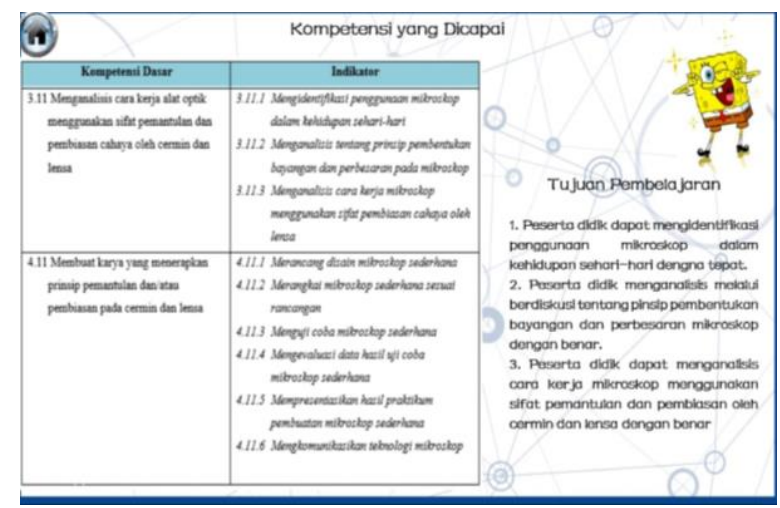

Figure 3. Performance of competency section 


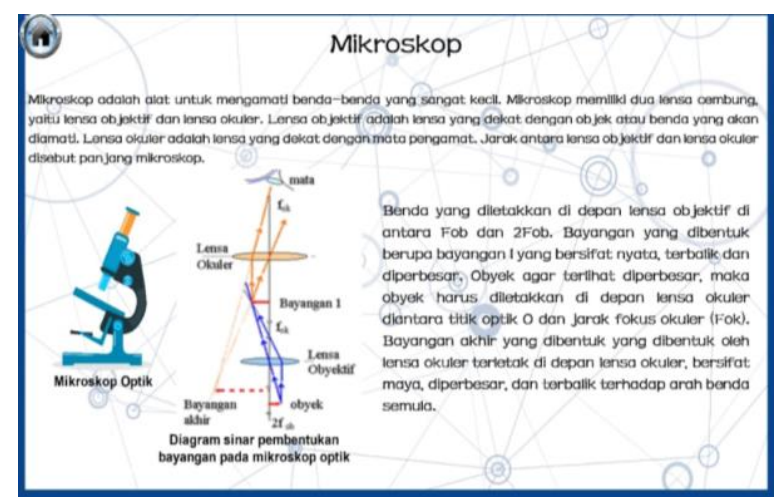

Figure 4. Performance of material section

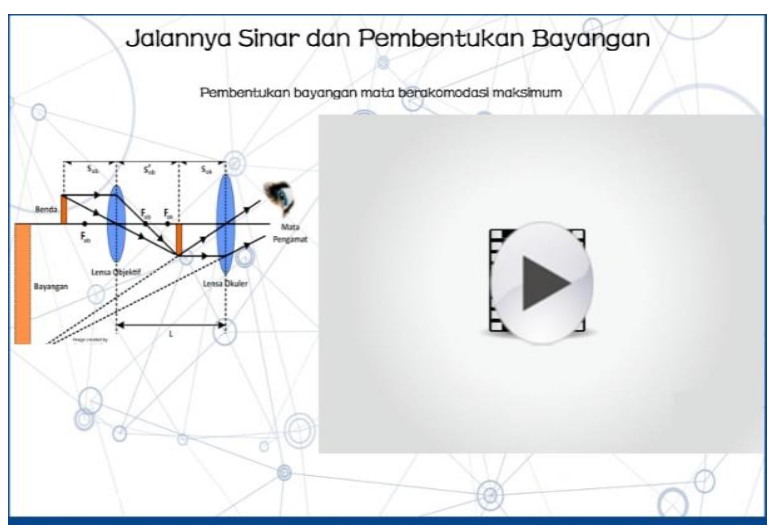

Figure 5. Performance of the material in the form of videos and illustration

Smartphone-based physics learning media that has been developed were then validated by experts to get improvements. The results of product improvements were then used to be tested on students (Main field testing). The trial stage for students was carried out by implementing the product in physics learning in school. The purpose of this stage was to determine the response of students to the media used. The results of students' responses to products were taken into consideration for product evaluation (Operational product revision). So, the results of the validation of the smartphone-based physics learning media on microscope topic were obtained from the assessment of experts and the responses of students.

\subsection{Validation and Evaluation Stage}

Products are developed following the design described above. Smartphone-based learning media that has been developed are then validated by content and media experts and tested for student practicality. The product was validated by two content experts and two media experts. The results of data analysis from each testing phase are described in the following points.

\subsubsection{Media Experts Validation}

The results of the media experts' assessment on the product are presented in Table 2.

Table 2. Media validation results by media experts

\begin{tabular}{|c|c|c|}
\hline Aspect & $\begin{array}{c}\text { Average } \\
\text { Score }\end{array}$ & Criteria \\
\hline Quality of content & 4 & Strongly Valid \\
\hline Language & 3 & Valid \\
\hline Implementation & 4 & Strongly Valid \\
\hline Visual appearance & 3.25 & Valid \\
\hline Sound aspect & 3 & Valid \\
\hline Easy to use & 3 & Valid \\
\hline $\begin{array}{c}\text { Average overall } \\
\text { aspects }\end{array}$ & 3.375 & Valid \\
\hline
\end{tabular}

Table 2 shows information on the results of media validation with 6 assessment aspects (content quality, language, feasibility, visual appearance, sound, easy to use). The results of media validation with an overall average show that the developed product has "valid" criteria. The results of this validation indicate that smartphone-based learning media is suitable for use in learning on microscope topics. The results of this study are supported by previous research [21][22].

\subsubsection{Content Expert Validation}

The results of the evaluation of the content experts' validation on the product are presented in Table 3.

Table 3. Content validation results by content expert validators

\begin{tabular}{|c|c|c|}
\hline Aspect & $\begin{array}{c}\text { Average } \\
\text { Score }\end{array}$ & Criteria \\
\hline Quality of content & 3.75 & Strongly Valid \\
\hline Language & 4 & Strongly Valid \\
\hline Implementation & 3.5 & Strongly Valid \\
\hline Visual appearance & 3.5 & Strongly Valid \\
\hline Sound aspect & 4 & Strongly Valid \\
\hline Easy to use & 4 & Strongly Valid \\
\hline $\begin{array}{c}\text { Average overall } \\
\text { aspects }\end{array}$ & 3.79 & Strongly Valid \\
\hline
\end{tabular}

Table 3 provides information on the results of content validation with 6 aspects of assessment (content quality, language, implementation, visual appearance, sound, easy to use). The results of the content validation with the overall average show that this product has "strongly valid" criteria. The results of this validation indicate that smartphone-based learning media is suitable for use in learning on microscope topic. The results of this study are supported by previous research [19]. 


\subsubsection{Students Responses}

The results of students' responses to this product are presented in Table 4.

Table 4. Students responses to learning media

\begin{tabular}{|c|c|l|}
\hline Aspect & $\begin{array}{c}\text { Average } \\
\text { Score }\end{array}$ & Criteria \\
\hline $\begin{array}{c}\text { Content and } \\
\text { objectives }\end{array}$ & 3,35 & Very Good \\
\hline Instructional & 3,48 & Very Good \\
\hline Technical & 3,73 & Very Good \\
\hline Language & 3,32 & Very Good \\
\hline $\begin{array}{c}\text { Average overall } \\
\text { aspects }\end{array}$ & 3,47 & Very Good \\
\hline
\end{tabular}

Table 4 shows information on the results of students' responses with 4 aspects of assessment (content and objectives, instructional, technical, and language). The results of students' responses with an average of all aspects showed that the developed product had "very good" criteria. The results of this validation indicate that smartphone-based learning media can be used properly by students [19] [21].

Smartphone-based learning media on microscope topic has very good criteria and is suitable for use for students of class XI MIPA based on the validation results. This smartphone-based learning media has been developed and can be used in the learning process. This learning media can be used both in class and outside the classroom and can help students get more meaningful learning [13] [14]. Previous research supports the results of this research that smartphonebased learning media helped students achieve learning indicators [16]. Other studies also support the results of this study which stated that learning media assisted by smartphones were suitable for use in educational units and support students in achieving their learning goals [15].

Smartphones as part of the latest technological developments affect education, in the curriculum [10], the learning process [13], and the results of the learning process using a smartphone [2] [14] [21]. The microscope topic that is integrated with the use of a smartphone is able to provide innovation in learning media and make it easier for students to understand the topic. Learning with smartphone-based media can be an alternative in school learning [14]. The use of smartphones in learning at school is undoubtedly necessary to get support from school regulations. The use of smartphones in the school environment is positive and optimal for advancing the nation's education.

\section{CONCLUSION}

The results of this research and development are in the form of smartphone-based physics learning media on the subject of optics with the microscope topic. The validation results of smartphone-based learning media by media experts and content experts showed that this learning media was feasible for use in the learning process with valid and very valid predicates. Students, as respondents, also showed a very good response to the use of this media. So, it can be concluded that smartphone-based physics learning media is suitable for use in learning physics on the microscope topic.

The use of smartphone-based learning media can be an alternative in learning. Learning in the classroom becomes more interesting and attractive. This research can also be an inspiration for further research to develop smartphone-based learning media on different subjects.

\section{REFERENCES}

[1] Y. Puji Lestari, Dampak Positif Pembelajaran Online dalam Sistem Pendidikan Indonesia Pasca Pandemi COVID-19, 'ADALAH: Buletin Hukum dan Keadilan 4(1) (2020) 49-56. DOI: https://doi.org/10.15408/adalah.v4i1.15394

[2] R. Yektyastuti, J. Ikhsan, Pengembangan Media Pembelajaran Berbasis Android pada Materi Kelarutan untuk Meningkatkan Performa Akademik Peserta Didik SMA Developing Android-Based Instructional Media of Solubility to Improve Academic Performance of High School Students, Jurnal Inovasi Pendidikan IPA 2(1) (2016) 88-99. DOI: http://dx.doi.org/10.21831/jipi.v2i1.10289

[3] S.A.K. Marhadini, I. Akhlis, I. Sumpono, Pengembangan Media Pembelajaran Berbasis Android pada Materi Gerak Parabola untuk Siswa SMA, Unnes Physics Education Journal 6(3) (2017) 38-43. DOI: https://doi.org/10.15294/upej.v6i3.19315

[4] I..R. Lubis, J. Ikhsan, Pengembangan Media Pembelajaran Kimia Berbasis Android untuk Meningkatkan Motivasi Belajar dan Prestasi Kognitif Peserta Didik SMA, Jurnal Inovasi Pendidikan IPA 1(2) (2015) 191-201. DOI: https://doi.org/10.21831/jipi.v1i2.7504

[5] E. Setyaningsih, A. Sunandar, A.E. Setiadi, Pengembangan Media Booklet Berbasis Potensi Lokal Kalimantan Barat pada Materi Keanekaragaman Hayati pada Siswa Kelas X di 
SMA Muhammadiyah 1 Pontianak, Jurnal Pedagogi Hayati 3(1) (2019) 44-52. DOI: https://doi.org/10.31629/ph.v3i1.1068

[6] C. Odgers, Smartphones are Bad for Some Teens, Nature 554 (2018) 432-434. DOI: https://doi.org/10.1038/d41586-018-02109-8

[7] L. Han, H. Yan, Investigating The Impacts of Family Restriction Strategy on Chinese Children's Smartphone Use Behaviors, in: Proceedings of the Association for Information Science and Technology, vol. 56, John Wiley \& Sons, Melbourne, 2019, pp. 664-666. DOI: https://doi.org/10.1002/pra2.126

[8] P.F Bachtiar, N.K. Fithri, R. Amalia, C.K. Herbawani, Suci Wahyu Ismiyasa, Edukasi Mengenai Dampak Penggunaan Smartphone sebagai Upaya Pencegahan Gangguan Muskuloskeletal pada Remaja, Abdimas Unwahas 5(1) (2020) 28-32. DOI: http://dx.doi.org/10.31942/abd.v5i1.3332

[9] F.S. Arista, H. Kuswanto, Virtual Physics Laboratory Application Based on The Android Smartphone to Improve Learning Independence and Conceptual Understanding, International Journal Instruction 11(1) (2018) 1-16. DOI: https://doi.org/10.12973/iji.2018.1111a

[10] Ü. Aktürk, F. Budak, A. Gültekin, A. Özdemir, Comparison of Smartphone Addiction and Loneliness in High School and University Students, Perspective Psychiatry Care 54(4) (2018) 1-7. DOI: https://doi.org/10.1111/ppc.12277

[11] S. Muyaroah, M. Fajartia, Pengembangan Media Pembelajaran Berbasis Android dengan menggunakan Aplikasi Adobe Flash CS 6 pada Mata Pelajaran Biologi, Innovation Journal Curricullum Education Technology 6(2) (2017) 79-83.

DOI: https://doi.org/10.15294/IJCET.V6I2.19336

[12] N.K. Agarwal, W. Lu, Toward effective use and balance: investigating pros and cons of smartphone use in an interview study, in: proceedings of the association for information Science and Technology, vol. 56, John Wiley \& Sons, Boston, 2019, pp. 594-596, DOI: https://doi.org/10.1002/pra2.100

[13] M. Miyake, K. Takeuchi, Y. Toda, Variations of Perspectives of Junior High School Students Who have Participated in Smartphone Summit for Appropriate Usage of The Internet and Smartphones, Pastoral Care in Education 26(2) (2018) 1-13. DOI: https://doi.org/10.1080/02643944.2018.1464592

[14] A.D. Fatma, C.F. Partana, Pembelajaran Berbantu Aplikasi Android untuk Meningkatkan Kemampuan Pemecahan Masalah Kimia Learning with Android Application to Improve Chemical Problem Solving Ability, Jurnal Inovasi Pendidikan IPA 5(2) (2019) 229-236. DOI: https://doi.org/10.21831/jipi.v5i2.26035

[15] S. Ma, D.G. Steger, P.E. Doolittle, A.C. Stewart, Improved Academic Performance and Student Perceptions of Learning Through Use of a Cell Phone-Based Personal Response System, Journal Food Science Education 17(1) (2018) 27-32. DOI: $\underline{\text { https://doi.org/10.1111/1541-4329.12131 }}$

[16] S.R. Kang, H. Shin, J.M. Lee, S.J. Kim, Effects of Smartphone Application Education Combined With Hands-On Practice in Breast SelfExamination on Junior Nursing Students in South Korea, Japan Journal Nurse Science 17(3) (2020) 1-13. DOI: https://doi.org/10.1111/jjns.12318

[17] S. Han, R. Rosli, M.M. Capraro, R.M. Capraro, The Effect of Science, Technology, Engineering and Mathematics (STEM) Project Based Learning (PBL) on Students' Achievement in Four Mathematics Topics, Journal Turkish Science Education 13 (2016) 3-29. DOI: https://doi.org/10.12973/tused.10168a

[18] D.U. Bolliger, D. McCoy, T. Kilty, C.E. Shepherd, Smartphone Use in Outdoor Education: A Question of Activity Progression and Place, Journal Adventure Education Outdoor Learning 19(1) (2020) 1-14. DOI: https://doi.org/10.1080/14729679.2020.1730204

[19] R. Istiawan, Mosik, A. Sopyan, Pengembangan Media Prezi Mind Map untuk Meningkatkan Pemahaman Konsep Fisika Materi Alat Optik pada Siswa SMA Kelas X Peminatan IPS, Unnes Physics Education Journal 5(3) (2016) 87-93. DOI: https://doi.org/10.15294/upej.v5i3.8722

[20] N.N. Putri, Subiki, Sudarti, Pengembangan Media Pembelajaran Fisika Berbasis Android Berbantuan Web Appsgyeser pada Materi Alatalat Optik Kelas XI di SMA, Jurnal Pembelajaran Fisika 8(4) (2019) 254-261 DOI: https://doi.org/10.19184/jpf.v8i4.15234 
[21] M. Arif, Festiyed, Desnita, and W.S. Dewi, Pembuatan Bahan Ajar Berbasis Android untuk Pembelajaran Fisika pada Materi Gelombang Bunyi, Gelombang Cahaya dan Alat Optik di Kelas XI SMA/MA, Pillar Physics Education 12(3) (2019) 1-8. DOI: http://dx.doi.org/10.24036/7075171074

[22] V.W. Suryaningtyas, R.A. Nugroho, S.P. Cahyono, M.R. Nababan, R. Santosa, Translation Learning Enrichment Using Smart Application Creator 3.0: An Attempt to Design a Mobile Application in Translation for Tourism Purpose Course, in: 2019 International Seminar on Application for Technology of Information and Communication (iSemantic), IEEE Press, Piscataway, NJ, 2019, pp. 542-547. DOI: https://doi.org/10.1109/ISEMANTIC.2019.8884 273

[23] R. Tesi Muskania, I. Wilujeng, Pengembangan Perangkat Pembelajaran Project-Based Learning untuk Membekali Foundational Knowledge dan Meningkatkan Scientific Literacy, Cakrawala Pendidikan 36(1) (2017) 34-43. DOI: https://doi.org/10.21831/cp.v36i1.8830

[24] N. Nadhiroh, S. Latifah, Higher Order Thinking Skill (HOTS)-Based Student's Worksheet in Thermodynamics Material, Indonesian Journal Science Mathematics Education 3(1) (2020) 8795.

DOI:

https://doi.org/10.24042/ijsme.v3i1.6082

[25] D. Hamka, N. Effendi, Pengembangan Media Pembelajaran Blended Learning Berbasis Edmodo Pada Mata Kuliah Fisika Dasar di Program Studi Pendidikan IPA, Journal National Science and Integration 2(1) (2019) 19. DOI: http://dx.doi.org/10.24014/jnsi.v2i1.7111

[26] K.M. Rahmawati, S.H.B. Prastowo, S. Bektiarso, Pengembangan Bahan Ajar Fisika Berbasis Scientific Approach untuk Meningkatkan Kemampuan Berpikir Kritis Siswa pada Materi Medan Magnet di SMA, Jurnal Pembelajaran Fisika 8(2) (2019) 80-86. DOI: https://doi.org/10.19184/jpf.v8i2.11663

[27] I. F. Rofiqoh, Subiki, A.S. Budiarso, Identifikasi Kemampuan Berpikir Kreatif Siswa dengan Metode Mind Mapping pada Pembelajaran Fisika Pokok Bahasan Optik di SMA, Jurnal Pembelajaran Fiska 9(4) (2020) 139-146. DOI: https://doi.org/10.19184/jpf.v9i4.18359
[28] W. Wati, H. Istiqomah, Game Edukasi Fisika Berbasis Smartphone Android sebagai Media Pembelajaran Fisika, Indonesian Journal Science Mathematics Education 2(2) (2019) 162-167. DOI: https://doi.org/10.24042/ijsme.v2i2.4341

[29] S. Han, Y.J. Yi, How Does The Smartphone Usage of College Students Affect Academic Performance?, Journal of Computer Assisted Learning 35(1) (2018) 1-10. DOI: https://doi.org/10.1111/jcal.12306 